\title{
Ampelopsin reduces the migration and invasion of ovarian cancer cells via inhibition of epithelial-to-mesenchymal transition
}

\author{
TIANFENG LIU ${ }^{1,2}$, PEISHU LIU ${ }^{1}$, FENG DING ${ }^{2}$, NINA YU ${ }^{2}$, SHIHONG LI $^{2}$, SURONG WANG $^{2}$, \\ XIAOFEI ZHANG ${ }^{2}$, XIANGXIU SUN ${ }^{2}$, YING $\mathrm{CHEN}^{2}, \mathrm{FENG} \mathrm{WANG}^{3}$, YUNHE ZHAO ${ }^{4}$ and BO $\mathrm{LI}^{4}$ \\ ${ }^{1}$ Department of Gynecology, Qilu Hospital of Shandong University, Jinan, Shandong; ${ }^{2}$ Department of Gynecology, \\ Linyi People's Hospital, Linyi, Shandong, P.R. China; ${ }^{3}$ Department of Psychiatry, University of Illinois at Chicago, \\ Chicago, IL, USA; ${ }^{4}$ Department of Cardiology, Central Hospital of Zibo, Zibo, Shandong, P.R. China
}

Received August 25, 2014; Accepted November 19, 2014

DOI: $10.3892 / o r .2014 .3672$

\begin{abstract}
Ampelopsin has displayed anticancer activity in several types of cancers. However, no evidence has been reported for the direct effect of ampelopsin on ovarian cancer cell migration and invasion, and the underling mechanisms have not yet been clearly established. The aim of the present study was to investigate the influence of ampelopsin on the migration and invasion of ovarian cancer. Proliferation and viability of the ovarian cancer cells were detected by MTT assay. Migration and invasion of the cells were detected, respectively, by scratch wound healing assay and Transwell assay. The expression levels of epithelial-to-mesenchymal transition (EMT) markers were detected at the protein level after stimulation with ampelopsin. Then, the expression levels of NF- $\kappa \mathrm{B}$ and $\mathrm{p}-\mathrm{I} \kappa \mathrm{B} \alpha$ were detected with western blot analysis. Meanwhile, an inhibitor of NF- $\kappa \mathrm{B}$ was used to investigate the effect of ampelopsin. Finally, the expression of Snail was also detected. Proliferation, migration and invasion of the A2780 cells were all inhibited following the application of ampelopsin. Ampelopsin upregulated E-cadherin and downregulated $\mathrm{N}$-cadherin and vimentin in a concentration- and time-dependent manner. Ampelopsin also exerted its ability to suppress the nuclear translocation of the NF- $\kappa \mathrm{B}$ pathway. Administration of the inhibitor BAY11-7082 confirmed the roles of NF- $\mathrm{KB}$ in the expression of EMT markers and its transcription factor. These results demonstrated that ampelopsin inhibited EMT and reduced the invasion of ovarian cancer cells via the NF- $\mathrm{KB} /$ Snail pathway.
\end{abstract}

Correspondence to: Dr Peishu Liu, Department of Gynecology, Qilu Hospital of Shandong University, 107 West Culture Road, Jinan, Shandong 250012, P.R. China

E-mail: peishuliu@126.com

Dr Bo Li, Department of Cardiology, Central Hospital of Zibo, 54 Gong Qing Tuan Xi Road, Zibo, Shandong 255036, P.R. China E-mail: libosubmit@163.com

Key words: ampelopsin, NF-kB, Snail, epithelial-to-mesenchymal transition

\section{Introduction}

Ovarian cancer is one of the most prevalent cancers and has the highest mortality rate among women with gynecological malignancies (1). Without an effective method of early detection and due to the highly invasive property of ovarian cancer cells, the majority of patients suffer distant metastasis at the time of diagnosis. It has been shown that approximately $70-80 \%$ of patients with ovarian cancer of stage III and stage IV die within 5 years of diagnosis, even when undergoing aggressive cytoreductive surgery and combination chemotherapy (2). Therefore, it is urgent to elucidate the molecular mechanisms associated with ovarian cancer metastasis and to identify new therapeutic approaches, in order to achieve better treatment outcome.

In recent years, accumulating evidence has demonstrated that epithelial-to-mesenchymal transition (EMT), which is a morphologic conversion process that was first described in the context of embryogenesis, is associated with the acquisition of mesenchymal phenotypes and malignant characteristics in ovarian cancer cells, representing mechanisms of escaping from apoptosis and migrating through the extracellular environment (3-5). Loss of the epithelial molecule E-cadherin and gain of mesenchymal markers $\mathrm{N}$-cadherin and vimentin have been considered as the most important hallmarks of EMT (5). Among the stimuli that trigger EMT, Snail family members, including Snail, Slug, Twist, Zeb1 and SIP1, have been found to play an important role in promoting EMT (4).

Ampelopsin [(2R,3R)-3,5,7-trihydroxy-2-(3,4,5-trihydroxyphenyl)-2,3-dihydrochromen-4-one] (Fig. 1A), also called dihydromyricetin, is a type of flavonoid and is isolated from the stems and leaves of Ampelopsis grossedentata. Numerous pharmacological activities of ampelopsin have been reported, such as anti-inflammatory (6), antioxidant, and antimicrobial activity (7). In recent years, ampelopsin has been described to possess anticancer activity in various types of cancers. Ampelopsin was found to inhibit the growth and invasion of breast cancer cells in vitro (8), and to inhibit the growth of prostate cancer in vivo (9). Ampelopsin also showed activity for inhibiting vascular endothelial growth factor (VEGF) and basic fibroblast growth factor (bFGF), suppressing angiogenesis in hepatocellular carcinoma (10). However, no evidence 
has been reported for the direct effect of ampelopsin on ovarian cancer cell invasion and the mechanisms of this effect.

The present study was designed to investigate the effects of ampelopsin on ovarian cancer cell migration and invasion, as well as its influence on EMT.

\section{Materials and methods}

Reagents. Ampelopsin was purchased from Sigma-Aldrich (St. Louis, MO, USA). Rabbit monoclonal to E-cadherin and vimentin antibodies were from Abcam (Cambridge, UK). Rabbit polyclonal to N-cadherin, Snail and GAPDH were also from Abcam. Rabbit anti-mouse antibodies for NF- $\mathrm{B}$ (p65) and $\mathrm{I} \kappa \mathrm{B} \alpha$ were both purchased from Cell Signaling Technology Inc. (Danvers, MA, USA). BAY11-7082, a selective inhibitor of NF- $\mathrm{B}$, was purchased from Sigma-Aldrich.

Cell culture. The A2780 cell line (human ovarian cancer cell line) was obtained from the American Type Culture Collection (Manassas, VA, USA), and was cultured in RPMI-1640 (HyClone Laboratories, Inc., Logan, UT, USA) supplemented with $10 \%$ fetal bovine serum (FBS) (HyClone) in an atmosphere containing $5 \% \mathrm{CO}_{2}$.

Cell viability and proliferation assay. Cell viability and proliferation activity were assessed with the MTT colorimetric assay. A2780 cells were seeded into 96-well plates (Corning Inc., Corning, NY, USA) at a concentration of 5,000 cells/well. After stimulation with ampelopsin of various concentrations $(0,5,10,25$, and $50 \mu \mathrm{M})$ for various time-points $(0,1,3,6$, $12,24$, and $48 \mathrm{~h})$, MTT $(5 \mu \mathrm{g} / \mathrm{ml}, 20 \mu \mathrm{l})$ was added into each well for a 4-h incubation. Then, $80 \mu \mathrm{l}$ of dimethyl sulfoxide (DMSO) (Sigma-Aldrich) was added for another $15 \mathrm{~min}$ to fully solubilize the formazan (the metabolic product of MTT). Finally, the liberated purple product was detected using a microplate luminometer at $490 \mathrm{~nm}$.

Scratch wound healing assay. A scratch wound healing assay was used to evaluate the migratory ability of the A2780 cells. A2780 cells (1x10\% $/$ well, Corning Inc.) were cultured in 6-well plates. Straight scratches of the same width were made in the monolayer of A2780 cells with a pipette tip. After incubation with ampelopsin of $25 \mu \mathrm{M}$ for $24 \mathrm{~h}$, images were captured to measure the wound healing under a microscope.

Transwell assay. The effect of ampelopsin on the invasive ability of the A2780 cells was detected with modified Boyden chambers with $8-\mu \mathrm{m}$ pore filter inserts (Corning Inc.). The A2780 cells were cultured in 24-well plates, and the upper chamber contained cells in RPMI-1640 plus $1 \%$ FBS, while the lower chamber contained RPMI-1640 plus $10 \%$ FBS. Cells $\left(1 \times 10^{5} /\right.$ well) were re-suspended in the upper chamber at $37^{\circ} \mathrm{C}$ in $5 \% \mathrm{CO}_{2}$. After a 24-h-incubation, the cells on the lower surface were fixed with methanol for $30 \mathrm{~min}$ and stained with hexamethylpararosaniline, while the cells remaining on the upper surface were wiped away.

Western blot analysis. After stimulation, the A2780 cells were collected and lysed. The extracted protein concentration was measured using BCA protein assay kit (Beyotime
Biotechnology, China). Proteins of equal amounts were separated via $10 \%$ SDS-polyacrylamide gel, and transferred onto nitrocellulose (NC) membranes (Millipore, Billerica, MA, USA). Blots were blocked and incubated with the primary antibodies followed by incubation with the secondary antibodies. Finally, the blots were visualized with electrochemiluminescence (ECL) detection system (Millipore).

Statistical analysis. All data in the present study were evaluated with predictive analytics software (PASW) statistics 18.0 (SPSS Inc., Chicago, IL, USA). The normally distributed data were analyzed by one-way ANOVA and the non-parametric variables were analyzed by the Mann-Whitney $U$ test. Statistical significance was confirmed as $\mathrm{P}<0.05$.

\section{Results}

Ampelopsin inhibits the proliferation of ovarian cancer cells. To clarify the specific role of ampelopsin in ovarian cancer cell proliferation, various concentrations $(0,5,10,25$, and $50 \mu \mathrm{M}$ ) of ampelopsin were added into the cultured A2780 cells. As shown in Fig. 1B, after a 24-h incubation at $50 \mu \mathrm{M}$, ampelopsin significantly inhibited the cell viability as detected by MTT assay. However, at concentrations below $50 \mu \mathrm{M}(5,10$, and $25 \mu \mathrm{M})$, the inhibition was not significant. Subsequently, 25 and $50 \mu \mathrm{M}$ of ampelopsin were selected to stimulate the cells for different times $(0,1,3,6,12,24$ and $48 \mathrm{~h}$ ). As shown in Fig. 1C, ampelopsin of $50 \mu \mathrm{M}$ significantly inhibited the proliferation after a 24-h stimulation, while ampelopsin of $25 \mu \mathrm{M}$ did not inhibit the proliferation after a 48 -h stimulation. As a result, we chose $25 \mu \mathrm{M}$ of ampelopsin for the subsequent migration and invasion experiments so that the influence of proliferation was excluded.

Ampelopsin inhibits the migration and invasion of ovarian cancer cells. A wound healing assay was used to assess the migration of the ovarian cancer cells, while a Transwell assay was applied to evaluate the invasion of the ovarian cancer cells. A2780 ovarian cancer cells were treated with ampelopsin at the concentration of $25 \mu \mathrm{M}$ for $24 \mathrm{~h}$. As shown in Fig. 2A, the results of the wound healing assay demonstrated that healing over the scratch was significantly reduced after treatment with ampelopsin. As shown in Fig. 2B, the results of the Transwell assay demonstrated that the number of invading cells migrating from the upper to the lower surface was also significantly reduced after treatment with ampelopsin.

Effects of ampelopsin on expression of EMT markers in the ovarian cancer cells. EMT is thought to play an important role in the process of cancer cell migration and invasion. We thus assessed the effect of ampelopsin on EMT marker expression in the A2780 ovarian cancer cells by western blot analysis. Various concentrations of ampelopsin $(5,10,25$, and $50 \mu \mathrm{M})$ were respectively added to the cells, and the cancer cells were cultured for another $12 \mathrm{~h}$. As shown in Fig. 3A, ampelopsin treatment significantly increased the expression of epithelial marker E-cadherin and decreased the expression of mesenchymal markers $\mathrm{N}$-cadherin and vimentin in the A2780 cells. The results above suggest that ampelopsin may alter the expression of EMT markers in a concentration-dependent manner and 
<smiles>O=C1c2c(O)cc(O)cc2O[C@H](c2cc(O)c(O)c(O)c2)[C@@H]1O</smiles>
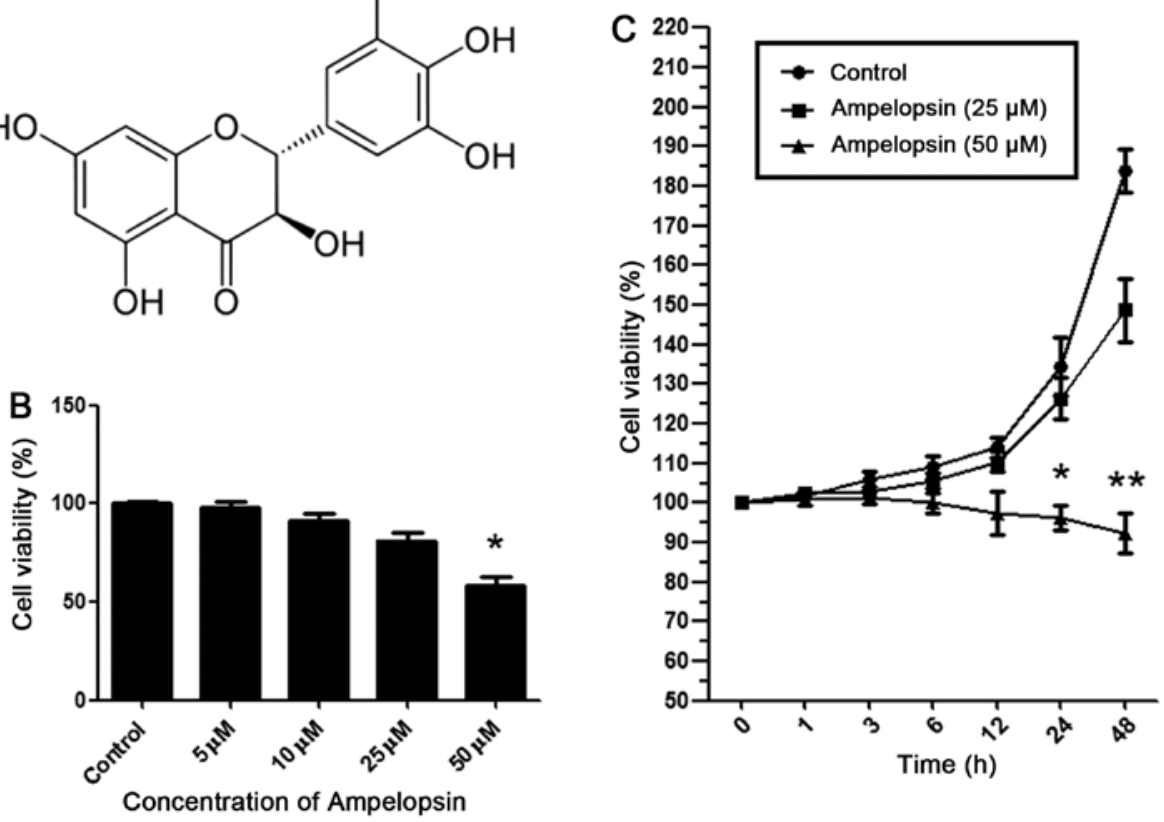

Figure 1. Ampelopsin inhibits the proliferation of A2780 ovarian cancer cells. (A) Chemical structure of ampelopsin. (B) After the A2780 cells were stimulated at $24 \mathrm{~h}$ with ampelopsin of different concentration gradients $(0,5,10,25$, and $50 \mu \mathrm{M})$, MTT assay was used to detect the viability of the A2780 cells. (C) After A2780 cells were stimulated with 0,25 and $50 \mu \mathrm{M}$ ampelopsin for different time periods $(0,1,3,6,12,24$ and $48 \mathrm{~h})$, MTT assay was used to detect the viability of the A2780 cells. ${ }^{*} \mathrm{P}<0.05 ;{ }^{* *} \mathrm{P}<0.01$ vs. the control group. Data shown are means \pm SEM from 3 independent experiments in duplicate.
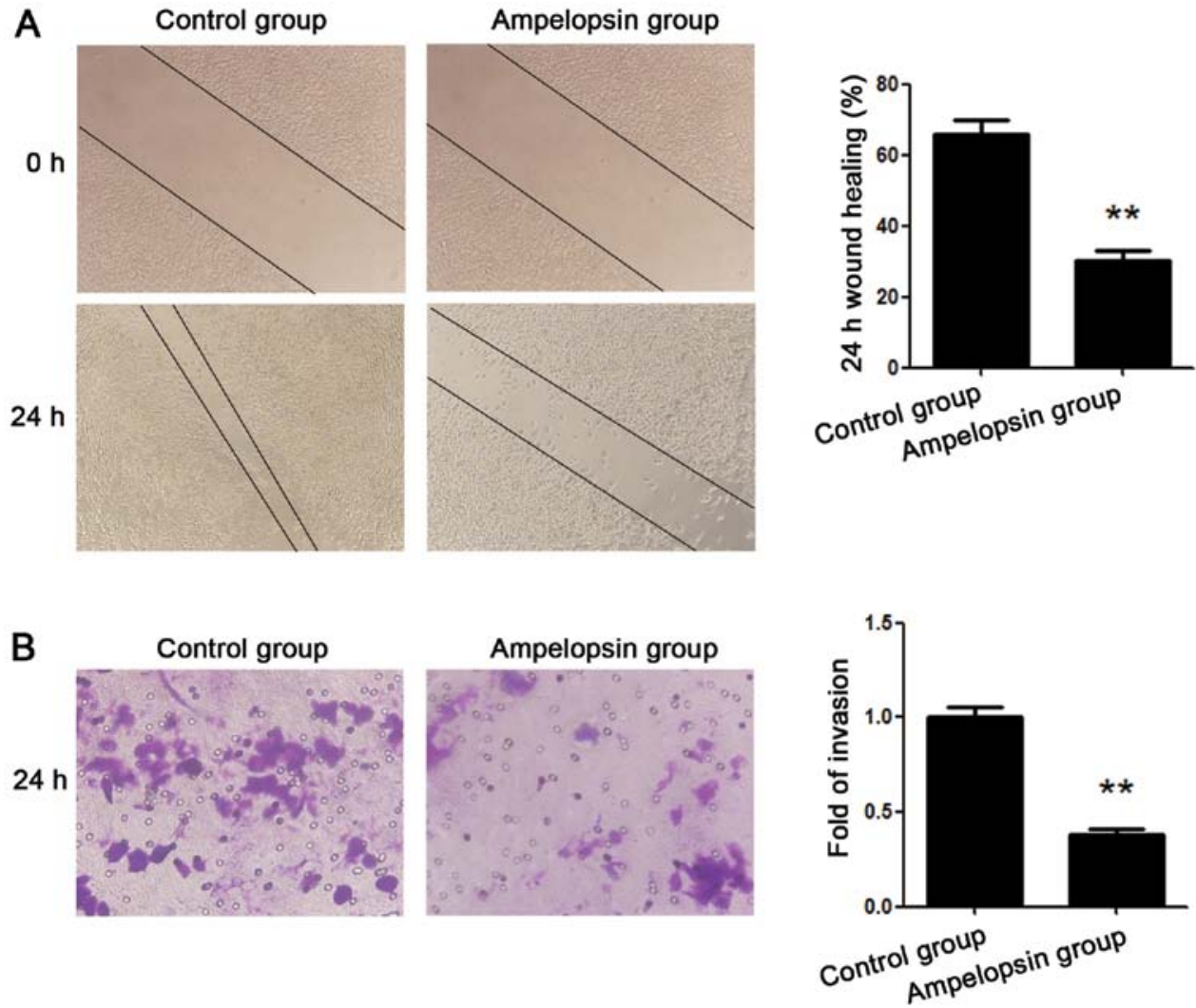

Figure 2. Ampelopsin inhibits the migration and invasion of A2780 ovarian cancer cells. (A) A2780 cells were treated with ampelopsin at the concentration of $25 \mu \mathrm{M}$ for $24 \mathrm{~h}$. The effect of ampelopsin on the migration of A2780 cells was assessed by a wound healing assay. (B) A2780 cells were treated with ampelopsin at the concentrations of $25 \mu \mathrm{M}$ for $24 \mathrm{~h}$. The effect of ampelopsin on invasion of A2780 ovarian cancer cells was assessed by a Transwell assay. ${ }^{* *} \mathrm{P}<0.01 \mathrm{vs}$. the control group. Data shown are means \pm SEM from 3 independent experiments in duplicate.

indicate that the inhibitory effect of ampelopsin on A2780 cell invasion and migration may be associated with EMT.
$N F-\kappa B$ pathway is involved in the anti-metastatic mechanism of ampelopsin. As a transcription factor, NF- $\mathrm{KB}$ shows a 

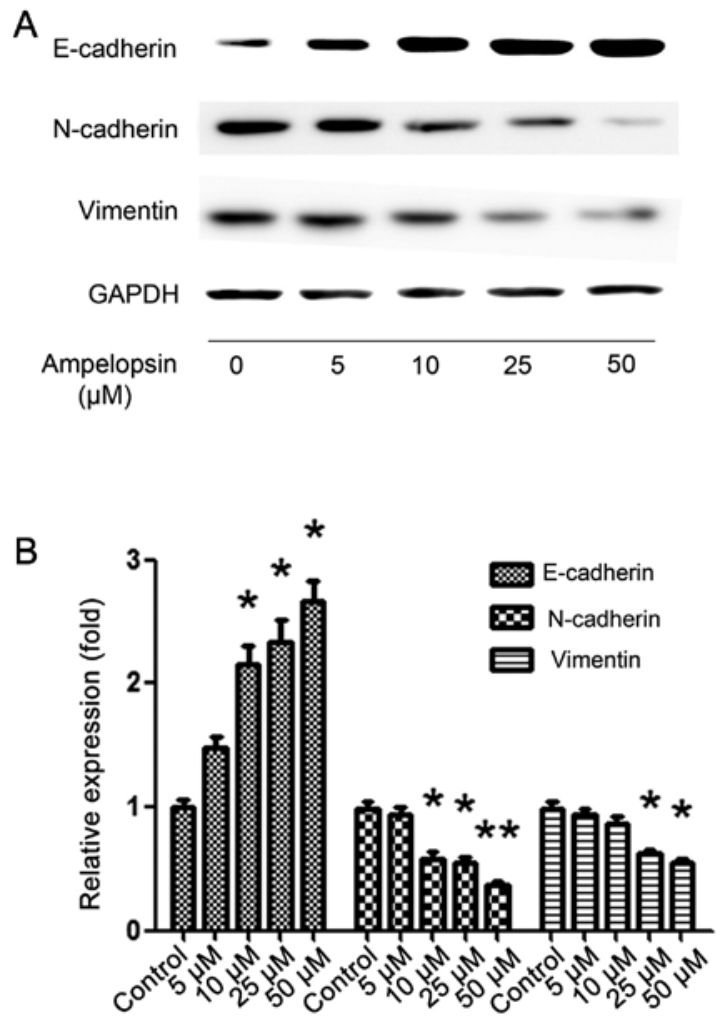

Figure 3. Ampelopsin increases the expression of E-cadherin and decreases the expression of $\mathrm{N}$-cadherin and vimentin. (A) A2780 ovarian cancer cells were treated with ampelopsin at various concentrations $(0,5,10,25$, and $50 \mu \mathrm{M}$ ) for $12 \mathrm{~h}$ and western blot analysis was utilized to assess the changes of E-cadherin, N-cadherin and vimentin protein expression. (B) Statistical analysis of the western blotting results. ${ }^{*} \mathrm{P}<0.05$ and ${ }^{* *} \mathrm{P}<0.01$ vs. the control group. Data shown are means \pm SEM from 3 independent experiments in duplicate.

significantly increased expression in ovarian cancer, and plays an important role in the aggressiveness of tumors $(11,12)$. $\mathrm{NF}-\kappa \mathrm{B}$ is tightly masked by its inhibitor protein $\mathrm{I} \kappa \mathrm{B}$ and thereby sequestered in the cytoplasm (13). Various stimulation signals may phosphorylate $\mathrm{I} \kappa \mathrm{B} \alpha$ and trigger a ubiquitination-mediated degradation of $\mathrm{I} \kappa \mathrm{B} \alpha(13)$, which allows phosphorylation of p65 and translocation of $\mathrm{NF}-\kappa \mathrm{B}$ from the cytoplasm to the nucleus where it binds with the promoter of its target genes. A previous study of pancreatic carcinoma cells demonstrated that blockage of $\mathrm{NF}-\kappa \mathrm{B}$ signaling may render cells resistant to TGF- $\beta$-induced EMT and then suppress migration and invasion (14). Thus, in the present study, we aimed to ascertain whether ampelopsin exerts its anti-metastatic effects and alters the expression of EMT markers via the NF- $\kappa \mathrm{B}$ pathway.

In order to determine the effects of ampelopsin on $\mathrm{NF}-\kappa \mathrm{B}$, we first stimulated the cells with different concentrations of ampelopsin $(5,10,25$ and $50 \mu \mathrm{M})$ for $12 \mathrm{~h}$. Then cytosol and nuclear proteins were extracted, respectively, followed by the detection of the expression of p65 and $\mathrm{I} \kappa \mathrm{B} \alpha$. As shown in Fig. 4A and B, ampelopsin significantly increased the expression of p65 in the cytosol but decreased its expression in the nucleus in a concentration-dependent manner. Meanwhile, the phosphorylation of $\mathrm{I} \kappa \mathrm{B} \alpha$ in the cytosol was decreased after ampelopsin treatment. Subsequently, to further determine the effect of $\mathrm{NF}-\kappa \mathrm{B}$ on the expression of EMT markers, we blocked the NF- $\kappa \mathrm{B}$ pathway by its inhibitor BAY11-7082
(20 $\mu \mathrm{M})$, which was chosen to pretreat the cells for $2 \mathrm{~h}$ before ampelopsin. As shown in Fig. 4C, BAY11-7082 significantly reversed ampelopsin-induced E-cadherin expression and $\mathrm{N}$-cadherin and vimentin expression. The results above indicate that $\mathrm{NF}-\kappa \mathrm{B}$ activation is critical for EMT and ampelopsin exerted its effect on cancer cell migration and invasion, as well as EMT, through suppressing the $\mathrm{NF}-\kappa \mathrm{B}$ pathway.

Ampelopsin induces Snail upregulation via $N F-\kappa B$ activation. As a complex multistep process occurring during tumor progression, EMT is governed by a variety of regulatory networks, in particular, the Snail family (15). Among the family members, Snail was the first described transcriptional repressor of E-cadherin and is the most extensively studied transcription factor. Thus, the effects of ampelopsin on the expression of Snail and the relationship between NF- $\kappa \mathrm{B}$ and Snail were investigated. We choose the concentration gradient of ampelopsin $(5,10,25$, and $50 \mu \mathrm{M})$ to stimulate the ovarian cancer cells for $24 \mathrm{~h}$. As shown in Fig. 5A, ampelopsin obviously suppresses the expression of Snail along with the increase in concentration, reaching a peak activity at the concentration of $50 \mu \mathrm{M}$. Then, the cells were also pretreated with BAY11$7082(20 \mu \mathrm{M})$ for $2 \mathrm{~h}$. As shown in Fig. 5B, pretreatment with the NF- $\kappa$ B inhibitor BAY11-7082 significantly abrogated the inhibitory effect of ampelopsin. These results indicate that $\mathrm{NF}-\kappa \mathrm{B}$ is a key regulator of Snail, and ampelopsin suppresses the expression of Snail through blocking the NF- $\kappa \mathrm{B}$ pathway at least in part.

\section{Discussion}

Metastasis is considered to be a primary cause of mortality among most ovarian cancer patients. Thus, understanding the molecular mechanisms of metastasis and searching for effective approaches to inhibit metastasis are the most important issues in cancer research. As a type of flavonoid extracted from Ampelopsis grossedentata, ampelopsin exhibits multiple functions in inflammation and oxidation. In recent years, more and more evidence suggests that ampelopsin has the ability to inhibit cell proliferation, migration and invasion in breast and prostate cancer. However, although the previous research (8-10) shed light on the action of ampelopsin's anticarcinogenesis, direct evidence involving ovarian cancer and the detailed molecular mechanisms have not been clearly elucidated.

As shown in a previous study (9), ampelopsin exhibits potent activity in inhibiting the proliferation of cancer cells by inducing apoptosis and downregulating Bcl-2. Thus, in the present study, we firstly detected the effect of ampelopsin on the viability of cultured cancer cells, and the results revealed that ampelopsin of $50 \mu \mathrm{M}$ significantly suppressed ovarian cancer cell proliferation after 24 and $48 \mathrm{~h}$ of incubation, while there was no difference at $12 \mathrm{~h}$. As a result, in the following experiments involving EMT markers, we selected $12 \mathrm{~h}$ as the stimulation time-point and $25 \mu \mathrm{M}$ as the stimulation concentration, so that the influence of proliferation was excluded. Subsequently, the wound healing and Transwell assays were respectively applied, and the results demonstrated that migration and invasion of ovarian cancer cells were both suppressed after incubation with ampelopsin, which indicated the antimetastatic activity of ampelopsin. 
A

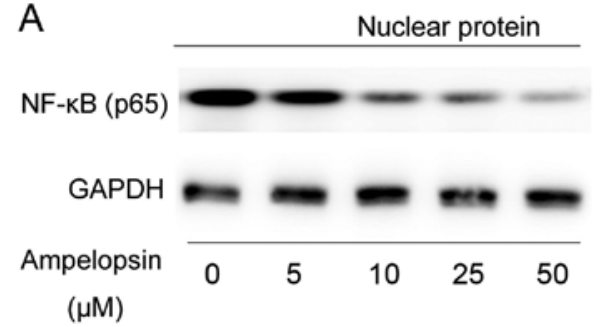

C

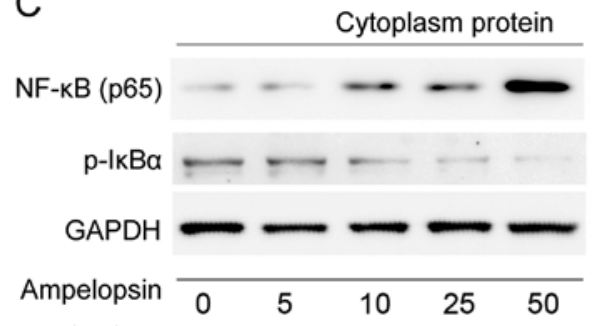

$(\mu \mathrm{M})$

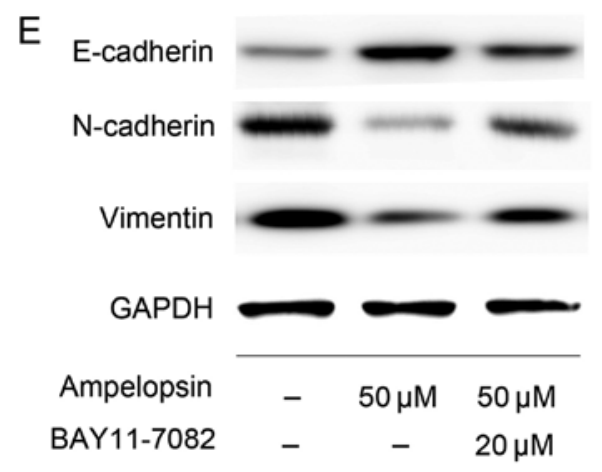

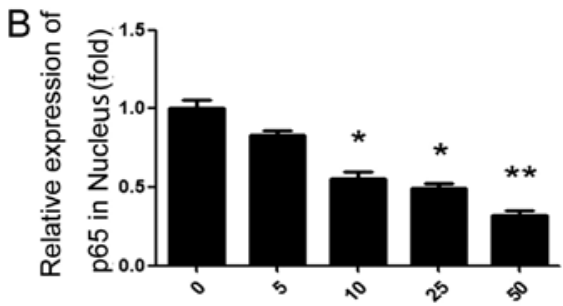

Concentration of Ampelopsin $(\mu \mathrm{M})$

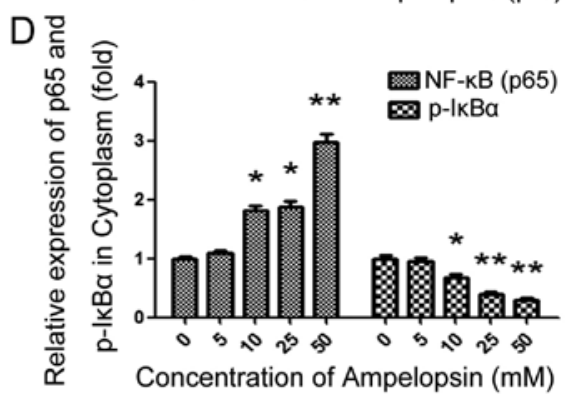

$\mathrm{F}$

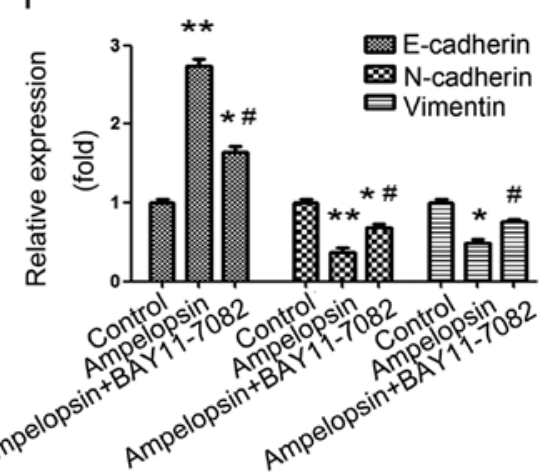

Figure 4. NF- $\mathrm{KB}$ mediates the regulation of epithelial-to-mesenchymal transition (EMT). (A and B) Treatment with ampelopsin for $12 \mathrm{~h}$ concentrationdependently decreased the expression of $\mathrm{p} 65$ in the nucleus. (C and D) Treatment with ampelopsin for $12 \mathrm{~h}$ concentration-dependently increased the expression of p65 in the cytosol, but decreased the phosphorylation of I $\mathrm{B} \alpha \alpha$ in the cytosol. (E and F) Western blot analysis showed that BAY11-7082 (20 $\mu \mathrm{M})$ significantly reversed the effects of ampelopsin on E-cadherin, $\mathrm{N}$-cadherin and vimentin protein expression. ${ }^{*} \mathrm{P}<0.05$ and ${ }^{* *} \mathrm{P}<0.01$ vs. the control group; ${ }^{*} \mathrm{P}<0.05$ vs. the ampelopsin group. Data shown are means \pm SEM from 3 independent experiments in duplicate.

A
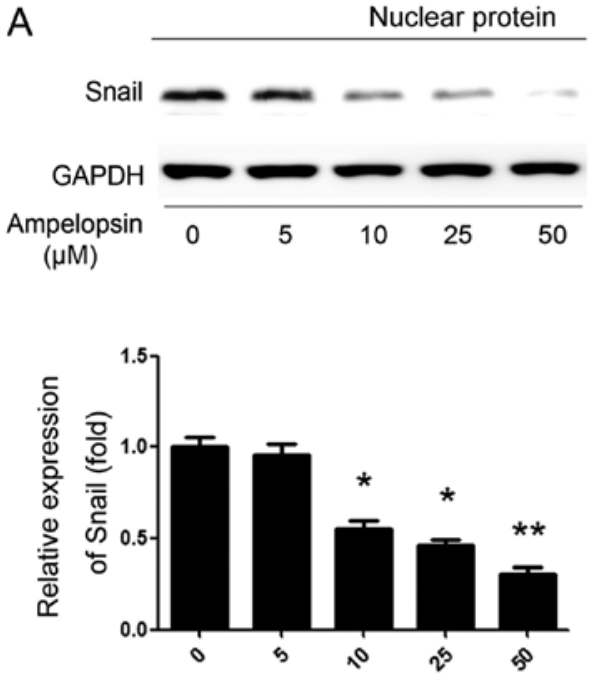

Concentration of Ampelopsin $(\mu \mathrm{M})$
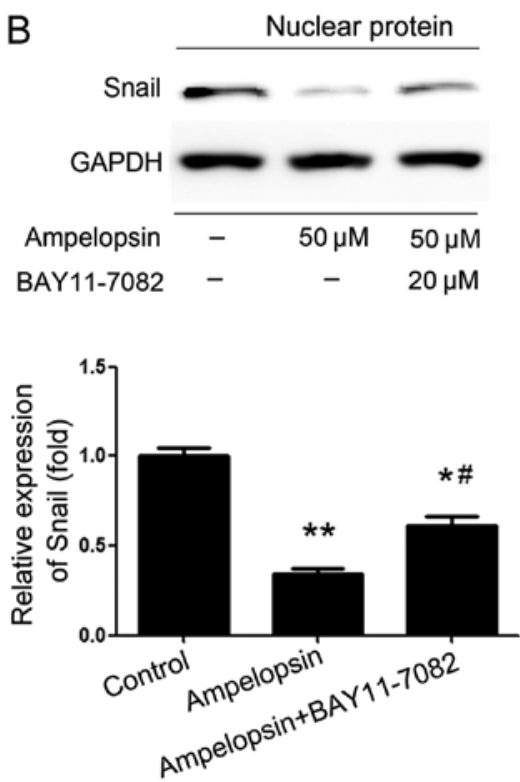

Figure 5. NF- $\mathrm{kB}$ mediates the regulation of Snail. (A) Treatment with ampelopsin for $12 \mathrm{~h}$ concentration-dependently decreased the expression of Snail in the nucleus. (B) Western blot analysis showed that BAY11-7082 $(20 \mu \mathrm{M})$ significantly reversed the effects of ampelopsin on Snail protein expression. "P $<0.05$ and ${ }^{* *} \mathrm{P}<0.01$ vs. the control group; ${ }^{*} \mathrm{P}<0.05$ vs. the ampelopsin group. Data shown are means \pm SEM from 3 independent experiments in duplicate. 
EMT, a developmental reprogramming process through which polarized, immotile epithelial cells undergo transdifferentiation into motile mesenchymal cells, is characterized by loss of epithelial markers, such as E-cadherin, and in turn, acquisition of mesenchymal markers, such as $\mathrm{N}$-cadherin and vimentin. Previous studies have demonstrated that, during ovarian cancer progression, EMT plays an important role in inducing matrix metalloproteinase production and in promoting dissemination of tumor cells, thereby increasing cell invasion and contributing to the poor outcome of ovarian cancer patients (16-18). In addition, evidence suggests that EMT has been found to give rise to resistance to chemotherapeutic drugs in ovarian cancer $(19,20)$. Therefore, in the present study, we aimed to ascertain the specific roles of ampelopsin in the metastasis of ovarian cancer cells, as well as the underlying relationship between ampelopsin and EMT. The results demonstrated that incubation with ampelopsin for $12 \mathrm{~h}$ concentration-dependently promoted the expression of epithelial marker E-cadherin, and inhibited mesenchymal markers $\mathrm{N}$-cadherin and vimentin, which indicated that EMT was promoted by ampelopsin in ovarian cancer cells.

$\mathrm{NF}-\kappa \mathrm{B}$, a pleiotropic transcription factor, plays important roles in pathological processes associated with cancer development, such as proliferation, migration, invasion, angiogenesis, drug resistance and inflammation (21-23). It was also found in previous studies that the induction of EMT was closely associated with the activation of $\mathrm{NF}-\kappa \mathrm{B}$. Cichon and Radisky found that ROS-induced EMT in mammary epithelial cells was mediated by NF-кB (24), while Liu and colleagues found that triptolide reversed hypoxia-induced EMT in pancreatic cancer by $\mathrm{NF}-\kappa \mathrm{B}$ downregulation (25). In addition, it was also reported in several other studies that EMT was induced by many factors via the NF- $\mathrm{KB}$ signaling pathway in hypopharyngeal cancer (26), tongue squamous cell carcinoma (27), and prostate cancer (28). In the present study, our results demonstrated that the expression of p65 in the cytosol was increased while its expression in the nucleus was decreased, which indicated that the inhibition of $\mathrm{NF}-\kappa \mathrm{B}$ nuclear translocation mediated the most important biological effects of $\mathrm{NF}-\kappa \mathrm{B}$. The phosphorylation of $\mathrm{I} \kappa \mathrm{B} \alpha$ in the cytosol, which is the major inhibitor of $\mathrm{NF}-\kappa \mathrm{B}$, was detected simultaneously, and its expression was decreased after ampelopsin treatment. Subsequently, the application of BAY11-7082 significantly reversed ampelopsin's effects on E-cadherin, $\mathrm{N}$-cadherin and vimentin expression, which further proved the important role of NF- $\kappa \mathrm{B}$ in the induction of EMT by ampelopsin.

Finally, we detected the effect of ampelopsin and NF- $\mathrm{BB}$ on transcription factor Snail. Snail, a zinc finger protein, is the most important member of the Snail superfamily. Previous studies have confirmed that it mediates EMT through downregulation of epithelial marker E-cadherin and upregulation of mesenchymal markers $\mathrm{N}$-cadherin and vimentin, through binding with several boxes in the promotor region (29). Snail is overexpressed in several types of cancers, especially in ovarian cancer, and has also been associated with tumor progression (30). Notably, Snail was also found to confer migration and invasion properties to cancer cells and promote carcinoma metastasis. The localization, expression and activity of Snail may be regulated by various factors, and the $N F-\kappa B$ signaling pathway is the most important and hackneyed mediator $(31,32)$. The results also revealed that ampelopsin concentration-dependently increased the expression of Snail in the nucleus, while BAY11-7082 significantly reversed the effects, further indicating that NF- $\kappa \mathrm{B}$ was upstream of Snail.

In summary, the present study firstly demonstrated that ampelopsin inhibited EMT and reduced the invasion of ovarian cancer cells. Moreover, the effect of ampelopsin was mediated by the NF- $\kappa \mathrm{B} /$ Snail signaling pathway. According to the results of the present study, the invasive ability of ovarian cancer cells may be restrained by ampelopsin by inhibiting the $\mathrm{NF}-\kappa \mathrm{B} / \mathrm{Snail}$ signaling pathway and EMT. Further in vivo studies should be performed.

\section{Acknowledgements}

This study was supported by the Natural Science Foundation of Shandong Province (no. 2012ZRE27087).

\section{References}

1. Haslehurst AM, Koti M, Dharsee M, Nuin P, Evans K, Geraci J, Childs T, Chen J, Li J, Weberpals J, Davey S, Squire J, Park PC and Feilotter H: EMT transcription factors snail and slug directly contribute to cisplatin resistance in ovarian cancer. BMC Cancer 12: 91, 2012.

2. Holschneider CH and Berek JS: Ovarian cancer: Epidemiology, biology, and prognostic factors. Sem Surg Oncol 19: 3-10, 2000.

3. Elloul S, Vaksman O, Stavnes HT, Trope CG, Davidson B and Reich R: Mesenchymal-to-epithelial transition determinants as characteristics of ovarian carcinoma effusions. Clin Exp Metastasis 27: 161-172, 2010.

4. Yuan H, Kajiyama H, Ito S, Yoshikawa N, Hyodo T, Asano E, Hasegawa $\mathrm{H}$, Maeda M, Shibata K, Hamaguchi M, Kikkawa F and Senga T: Alx1 induces snail expression to promote epithelial-to-mesenchymal transition and invasion of ovarian cancer cells. Cancer Res 73: 1581-1590, 2013.

5. Rosano L, Cianfrocca R, Spinella F, Di Castro V, Nicotra MR, Lucidi A, Ferrandina G, Natali PG and Bagnato A: Acquisition of chemoresistance and EMT phenotype is linked with activation of the endothelin A receptor pathway in ovarian carcinoma cells. Clin Cancer Res 17: 2350-2360, 2011.

6. Qi S, Xin Y, Guo Y, Diao Y, Kou X, Luo L and Yin Z: Ampelopsin reduces endotoxic inflammation via repressing ROS-mediated activation of $\mathrm{PI} 3 \mathrm{~K} / \mathrm{Akt} / \mathrm{NF}-\kappa \mathrm{B}$ signaling pathways. Int Immunopharmacol 12: 278-287, 2012.

7. Xie XF, Wang JW, Zhang HP, Li QX and Chen BY: Chemical composition, antimicrobial and antioxidant activities of essential oil from Ampelopsis megalophylla. Natural Prod Res 28: 853-860, 2014.

8. Zhou Y, Shu F, Liang X, Chang H, Shi L, Peng X, Zhu J and Mi M: Ampelopsin induces cell growth inhibition and apoptosis in breast cancer cells through ROS generation and endoplasmic reticulum stress pathway. PLoS One 9: e89021, 2014.

9. Ni F, Gong Y, Li L, Abdolmaleky HM and Zhou JR: Flavonoid ampelopsin inhibits the growth and metastasis of prostate cancer in vitro and in mice. PLoS One 7: e38802, 2012.

10. Luo GQ, Zeng S and Liu DY: Inhibitory effects of ampelopsin on angiogenesis. Zhong Yao Cai 29: 146-150, 2006 (In Chinese).

11. Wilson AJ, Barham W, Saskowski J, Tikhomirov O, Chen L, Lee HJ, Yull F and Khabele D: Tracking NF- $\kappa$ B activity in tumor cells during ovarian cancer progression in a syngeneic mouse model. J Ovarian Res 6: 63, 2013.

12. Nishio H, Yaguchi T, Sugiyama J, Sumimoto H, Umezawa K, Iwata T, Susumu N, Fujii T, Kawamura N, Kobayashi A, Park J, Aoki D and Kawakami Y: Immunosuppression through constitutively activated NF- $\mathrm{BB}$ signalling in human ovarian cancer and its reversal by an NF-кB inhibitor. Br J Cancer 110: 2965-2974, 2014.

13. Cianfrocca R, Tocci P, Semprucci E, Spinella F, Di Castro V, Bagnato A and Rosano L: $\beta$-arrestin 1 is required for endothelin-1-induced NF- $\kappa \mathrm{B}$ activation in ovarian cancer cells. Life Sci: Feb 12, 2014 (Epub ahead of print). doi: 10.1016/j. lfs.2014.01.078. 
14. Maier HJ, Schmidt-Strassburger U, Huber MA, Wiedemann EM, Beug $\mathrm{H}$ and Wirth T: NF-kappaB promotes epithelial-mesenchymal transition, migration and invasion of pancreatic carcinoma cells. Cancer Lett 295: 214-228, 2010.

15. Lu ZY, Dong R, Li D, Li WB, Xu FQ, Geng Y and Zhang YS: SNAI1 overexpression induces stemness and promotes ovarian cancer cell invasion and metastasis. Oncol Rep 27: 1587-1591, 2012.

16. Parikh A, Lee C, Peronne J, Marchini S, Baccarini A, Kolev V, Romualdi C, Fruscio R, Shah H, Wang F, Mullokandov G, Fishman D, D'Incalci M, Rahaman J, Kalir T, Redline RW, Brown BD, Narla G and DiFeo A: MicroRNA-181a has a critical role in ovarian cancer progression through the regulation of the epithelial-mesenchymal transition. Nat Commun 5: 2977, 2014.

17. Adham SA, Al Harrasi I, Al Haddabi I, Al Rashdi A, Al Sinawi S Al Maniri A, Ba-Omar T and Coomber BL: Immunohistological insight into the correlation between neuropilin-1 and epithelial mesenchymal transition markers in epithelial ovarian cancer. J Histochem Cytochem 62: 619-631, 2014.

18. Kim MK, Kim MA, Kim H, Kim YB and Song YS: Expression profiles of epithelial-mesenchymal transition-associated proteins in epithelial ovarian carcinoma. Biomed Res Int 2014: 495754, 2014.

19. Marchini S, Fruscio R, Clivio L, Beltrame L, Porcu L, Fuso Nerini I, Cavalieri D, Chiorino G, Cattoretti G, Mangioni C, Milani R, Torri V, Romualdi C, Zambelli A, Romano M, Signorelli M, di Giandomenico S and D'Incalci M: Resistance to platinum-based chemotherapy is associated with epithelial to mesenchymal transition in epithelial ovarian cancer. Eur J Cancer 49: 520-530, 2013.

20. Du F, Wu X, Liu Y, Wang T, Qi X, Mao Y, Jiang L, Zhu Y, Chen Y, Zhu R, Han X, Jin J, Ma X and Hua D: Acquisition of paclitaxel resistance via PI3K-dependent epithelial-mesenchymal transition in A2780 human ovarian cancer cells. Oncol Rep 30: 1113-1118, 2013.

21. Uno M, Saitoh Y, Mochida K, Tsuruyama E, Kiyono T, Imoto I Inazawa J, Yuasa Y, Kubota T and Yamaoka S: NF- $\mathrm{BB}$ inducing kinase, a central signaling component of the non-canonical pathway of NF- $\mathrm{BB}$, contributes to ovarian cancer progression. PLoS One 9: e88347, 2014.

22. Block MS, Charbonneau B, Vierkant RA, Fogarty Z, Bamlet WR, Pharoah PD, Rossing MA, Cramer D, Pearce CL, Schildkraut J, Menon U, Kjaer SK, Levine DA, Gronwald J, Culver HA, Whittemore AS, Karlan BY, Lambrechts D, Wentzensen N, Kupryjanczyk J, Chang-Claude J, Bandera EV, Hogdall E, Heitz F, Kaye SB, Fasching PA, Campbell I, Goodman MT, Pejovic T, Bean YT, Hays LE, Lurie G, Eccles D, Hein A, Beckmann MW, Ekici AB, Paul J, Brown R, Flanagan JM, Harter P, du Bois A, Schwaab I, Hogdall CK, Lundvall L, Olson SH, Orlow I, Paddock LE, Rudolph A, Eilber U, Dansonka-Mieszkowska A, Rzepecka IK, Ziolkowska-Seta I, Brinton LA, Yang H, Garcia-Closas M, Despierre E, Lambrechts S, Vergote I, Walsh CS, Lester J, Sieh W, McGuire V, Rothstein JH, Ziogas A, Lubinski J, Cybulski C, Menkiszak J, Jensen A, Gayther SA, Ramus SJ, Gentry-Maharaj A, Berchuck A, Wu AH, Pike MC, Van Den Berg D, Terry KL, Vitonis AF, Ramirez SM, Rider DN, Knutson KL, Sellers TA, Phelan CM, Doherty JA, Johnatty SE, deFazio A, Song H, Tyrer J, Kalli KR, Fridley BL, Cunningham JM and Goode EL: Variation in NF- $\kappa B$ signaling pathways and survival in invasive epithelial ovarian cancer. Cancer Epidemiol Biomarkers Prev 23: 1421-1427, 2014.
23. Annunziata CM, Stavnes HT, Kleinberg L, Berner A, Hernandez LF, Birrer MJ, Steinberg SM, Davidson B and Kohn EC: Nuclear factor kappaB transcription factors are coexpressed and convey a poor outcome in ovarian cancer. Cancer 116: 3276-3284, 2010.

24. Cichon MA and Radisky DC: ROS-induced epithelial-mesenchymal transition in mammary epithelial cells is mediated by $\mathrm{NF}-\kappa \mathrm{B}-$ dependent activation of Snail. Oncotarget 5: 2827-2838, 2014.

25. Liu L, Salnikov AV, Bauer N, Aleksandrowicz E, Labsch S, Nwaeburu C, Mattern J, Gladkich J, Schemmer P, Werner J and Herr I: Triptolide reverses hypoxia-induced epithelialmesenchymal transition and stem-like features in pancreatic cancer by NF- $\kappa \mathrm{B}$ downregulation. Int J Cancer 134: 24892503, 2014

26. Yu L, Mu Y, Sa N, Wang $\mathrm{H}$ and $\mathrm{Xu} \mathrm{W:} \mathrm{Tumor} \mathrm{necrosis} \mathrm{factor} \alpha$ induces epithelial-mesenchymal transition and promotes metastasis via $\mathrm{NF}-\kappa \mathrm{B}$ signaling pathway-mediated twist expression in hypopharyngeal cancer. Oncol Rep 31: 321-327, 2014.

27. Wang Y, Lin Z, Sun L, Fan S, Huang Z, Zhang D, Yang Z, $\mathrm{Li} \mathrm{J}$ and Chen W: Akt/Ezrin Tyr353/NF- $\mathrm{kB}$ pathway regulates EGF-induced EMT and metastasis in tongue squamous cell carcinoma. Br J Cancer 110: 695-705, 2014.

28. Deep G, Jain AK, Ramteke A, Ting H, Vijendra KC, Gangar SC, Agarwal C and Agarwal R: SNAI1 is critical for the aggressiveness of prostate cancer cells with low E-cadherin. Mol Cancer 13: 37, 2014.

29. Cano A, Perez-Moreno MA, Rodrigo I, Locascio A, Blanco MJ, del Barrio MG, Portillo F and Nieto MA. The transcription factor snail controls epithelial-mesenchymal transitions by repressing E-cadherin expression. Nat Cell Biol 2: 76-83, 2000.

30. Tuhkanen H, Soini Y, Kosma VM, Anttila M, Sironen R, Hamalainen K, Kukkonen L, Virtanen I and Mannermaa A: Nuclear expression of Snaill in borderline and malignant epithelial ovarian tumours is associated with tumour progression. BMC Cancer 9: 289, 2009.

31. Chen KC, Chen CY, Lin CR, Yang TY, Chen TH, Wu LC and $\mathrm{Wu} C \mathrm{C}$ : Luteolin attenuates TGF- $\beta 1$-induced epithelial-mesenchymal transition of lung cancer cells by interfering in the PI3K/Akt-NF- $\kappa \mathrm{B}-$ Snail pathway. Life Sci 93: 924-933, 2013.

32. Chen Z, Liu M, Liu X, Huang S, Li L, Song B, Li H, Ren Q, Hu Z, Zhou Y and Qiao L: COX-2 regulates E-cadherin expression through the NF- $\kappa \mathrm{B} /$ Snail signaling pathway in gastric cancer. Int J Mol Med 32: 93-100, 2013. 